\title{
Nature at Its Limits (Ecocide). Subjectivity After the Catastrophe
}

Aleksandra Ubertowska 


\section{Nature at Its Limits (Ecocide). Subjectivity After the Catastrophe}

DOI: 10.18318/td.2015.en.1.11

n the history of subjectivity, the current of non-anthropocentric humanities marks new and important caesuras which, it seems, once and for all dismantle late, modernist paradigms, essentialist fictions and demands based on foundations made up of "nature/culture", "human/animal", "internal/external", and "somatic/spiritual" distinctions. In his actor-network theory (ANT), Bruno Latour states that subjectivity (and psychology) are a plasmatic elemental force, circulating between various beings which are excluded by old typologies and which acquire the status of actants - beings endowed with the power of self-agency ${ }^{1}$. It is that self-agency, defined as an ability to influence other elements of the network, which takes over functions of exclusive subjectivity - a fact, which has certain consequences both in the sphere of epistemology, as well as politics. The monumental institutionalism of old societies is replaced in Latour's theory by softness of a cloth-net, always woven anew, in response to appeals of beings endangered by exclusion, ostracism and genocide.

An increasing number of interpretations, as Dominick LaCapra suggests, through observation of a fairytale-like

\author{
Aleksandra \\ Ubertowska - expert \\ in the study of \\ literature, professor \\ of Uniwersytet \\ Gdański; her research \\ interests include \\ the literature of \\ the Holocaust, \\ gender studies, the \\ problems associated \\ with identity \\ and ecocriticism. \\ Her articles were \\ published in "Teksty \\ Drugie,"'Pamiętnik \\ Literacki,"'Ruch \\ Literacki", as well as \\ in joint volumes of \\ Polish and non-Polish \\ publications (inter \\ alia Lexington Books, \\ Peter Lang, Akademie \\ Verlag).
}

1 Bruno Latour, Reassembling the Social, An Introduction to Actor-Network-Theory, (Oxford: Oxford University Press, 2005), 61-89, 201-220. 
phantasm, and a performative gesture $\mathbf{2}^{\mathbf{2}}$ or, as Giorgio Agamben suggests in his The Open. Man and Animal: the "movable boundary inside of a man"3, suggest the illusory character of ontological divisions such as "human/animal", "humans/(evil, destructive, alien) nature". According to Agamben, man is a product of the "anthropogenic machine", which fabricates a "human" in the body of a two-legged animal through isolation, or amputation of "naked life", an animalistic particle of being. Zoe becomes an object of marking, of enclosure in a concentration camp (a body of a muselmann), and simultaneously reminds us that "we are what we have lost". That is where the concept of integrating the lost particle of subjectivity, developed in The Open, came from. For Agamben, the acceptance of one's animal qualities has a salvation-like, utopian quality. In order to illustrate its essence, Agamben recalls the image and the aura of an apocalyptic feast on illustrations from the 13th-century Hebrew Bible found in the Biblioteca Ambrosiana collection. In the illustrations, figures of the righteous have been presented in human forms, but crowned with animal heads at the end of time and history.

In a comparable case, Jacques Derrida in his The Animal That Therefore IAm (L'animal que donc je suis, 20064), a collection of seminar lectures, investigates questions of "new subjectivity". The title contains a reference to the classical, Cartesian formula that embraces the essence of the human subject. Therefore, his correct sense would have been a little different, and far more iconoclastic ("I am an animal, therefore I am"). In his zoo-autobiography, Derrida - in contradistinction from many representatives of animal studies - does not remove the boundary between what is human and animal. On the contrary, he problematizes these two spheres profoundly, complicating their status (he calls his methodology "limitotrophy", or a method that feeds on the phenomenon of liminality like a parasite).

Therefore man and animal in Derrida's dissertation are separated by boundaries: diverse, folded, constantly accreting and, at the same time, cavernous. In order to define the nature of an animal, Derrida created

2 Dominick LaCapra, History and its Limits. Human, Animal, Violence, (New York: Cornell University Press, 2009), 151-154.

3 Giorgio Agamben, The Open. Man and Animal, trans. K. Attel, (Stanford: Stanford University Press, 2004), 15.

4 Jacques Derrida, L'animal que donc je suis, (Paris: Éditions Galilée, 2006). It is a posthumous collection of Derrida's lectures. I used a German translation by M. Sedlaczek: Jacques Derrida, Das Tier, das ich also bin, (Vienna: Passagen Verlag, 2010). 
a neologism: animot - an "animal word", assuming that an animal is merely (and as much as) a grapheme created by man, to whom God granted the right to name animals. The animot, within the Cartesian project, was supposed to reinforce the superior position of man in a world, cutting him off from the affective nature of an animal. In the end, it institutionalized boundaries and revealed their conventionality. The themes of limitotrophy and graphemes of Derrida's concept coincide within that very motive. The animot delineates a network of boundaries and folds that differentiate the identity claims of man. That deconstructionist gesture (stemming from a polemic with Heidegger) shows that man, to the same extent as an "animal", is "poor in the world" (weltarm), separated from language and truth about the essence of being. Man is also merely a place, where a subject can settle in; a subject that is far from any of its classical definitions. For purposes of his eco-critical lectures, Derrida constructed a new concept of subjectivity by writing that today the most important question seems to be about "a subject of compassion, co-feeling"7, about "I" immersed in, and not separated from, the environment.

Books and articles discussed here are linked by one particular theme, which locates eco-critical, philosophical reflections in a historical order, or more precisely - in a strictly defined context of "concentration camp universe", as the most radical emanation of bio-power, genocide or - in an even broader context - post-catastrophic consciousness. Relationships between post-catastrophic thought and literature and eco-criticism are diverse, penetrating and supplementing each other at many levels. It should not be too much of a simplification, if one were to state that a transition from "Holocaust studies" to political and literary studies ecology is a natural step in an intellectual development conditioned by the internal logic of both disciplines. Dominick LaCapra, a theoretician of trauma, is also involved in animal studies by no mere accident, while Giorgio Agamben combines reflections on "concentration camp universe" and the condition of the muselmann with essays on bio-power, and the history of interchangeability of the bios/zoe categories. The interception of concepts from the sphere of eco-criticism takes place at the level of rhetoric, through the exploitation of its internal performative potential. That is why Claud Lanzmann, when he talks about the effects of the Holocaust, employs the image of "deforestation"8 - climate changes resulting

6 lbid., 65 .

7 Ibid., 52.

8 Claude Lanzmann, "Der Ort und das Wort. Uber'Shoah'", in Niemand zeugt für den Zeugen, Erinnerungskultur nach der Shoah, ed. U. Baer, (Frankfurt am Main: Suhrkamp Verlag, 2000), 110. 
from the destruction of the Amazon rain forests - taken from contemporary ecology, while Jacques Derrida in his previously mentioned lectures, or Tadeusz Różewicz in his poems from the Grey Zone collection talk about the genocide of animals that undergo genetic experiments, or fall victim to industrial food processing practices.

The fact that environmentalism begins to broaden research horizons of the Holocaust studies is confirmed by Sybille Steinbacher's essay, in which she showed to what great extent the environment around Auschwitz, rich in water and swamps, (which was favourable to the industrial plans of the IG Farben Company which located its factory in the nearby town of Monowitz a theme known from the memoirs of Primo Levi) decided about the massive scale of the forced labor camp. One could say that in this particular case nature - a factor external to man - became a causative element of history, as understood by Richard Foltz ${ }^{\mathbf{1 0}}$.

Terminological borrowings go in the reverse direction as well: eco-criticism or, more broadly, environmental history, apply terms and descriptive categories, which function within the Holocaust and genocide studies. The widely commented book by David Zierler, The Invention of Ecocide: Agent Orange, Vietnam, and the Scientists Who Changed the Way We Think About the Environment"11, could serve as a good example. The concept of ecocide (by analogy to terms which function in the political sciences: genocide and ethnocide) was introduced by Arthur Galston, a bio-chemist, to describe the American military operation 'Ranch Hand', which consisted of spraying the South Vietnam territory with chemicals (herbicides). The operation led to the irreversible burning down of hectares of the jungle, which served as natural protection for Viet Cong soldiers.

Searching for affinities, which connect - at the level of lexis, methodology, or system of notions - the histories of extermination of entire groups of man, and devastation of nature is, it seems, motivated by a sensation that spheres, separated from each other, constitute an ecosystem that is impossible to grasp through description, which operates with anthropocentric research categories. Operation Ranch Hand transcended historical paradigms

Sybille Steinbacher, The Relationship of the Auschwitz Camp to the Outside Environment, Economy, and Society, in Lessons and Legacies VI. New Currents in Holocaust Research, ed. J. Diefendorf, (Evanston, Illinois: Northwestern University Press, 2004).

Richard C. Foltz, "Does Nature Have Historical Agency? World History, Environmental History, and How Historians Can Help Save the Planet", The History Teacher, vol 37, no 1 (2003): 9-28. 
(for example, the "Cold War" scheme, a conflict of two military superpowers), because its results had a trans-national character, which impacted the entire biological universe. That is why, for such a long time, it was not included in historiographic studies.

\section{Non-Human Factors Against the Nazi Tekhné}

In the light of the above observations, the need for reflection on the question of the extent to which Latour's perspective of broadening the formula of subjectivity with 'non-humans' remodels the understanding of postcatastrophism in literature and art, as well as what new perspectives it introduces to the question of inexpressibility/unpresentability of a traumatic experience becomes understandable. In the present essay I will be interested in the forms of visual and literary representations, in which the intervention of non-human factors in the sphere of traumatic experience, and the world after a catastrophe, has been presented in a radical way, causing a need for reformulation of existing cognitive and poetological schemes.

A touching essay by David L. Clark ${ }^{\mathbf{1 2}}$ about Bobby - a dog that accompanied Emmanuel Levinas in a work camp for French-Jewish prisoners of war (that turned out to be a last one in the Nazi Germany to believe in Kantian ethics) - brings back to mind an incredible, although relatively forgotten, film etude by Janusz Morgenstern entitled Ambulance (1961, screenplay by Tadeusz Łomnicki, score by Krzysztof Komeda). In that nineteen minute long movie an animal appears as well - an SS-Mann's guard dog (a "pedigree" German Shepherd, of course) that escorts a group of Jewish children to an ambulance, which performs the function of a gas chamber (it was an allusion to trucks used by Germans during the first stage of "Operation Reinhardt"). Scenes take place in a grim, ghastly space, in a petrifying emptiness of concrete slabs pressed against the backdrop of grey skies, which only strengthens the sensation of irreversibility of death. However, in a social "network" involved in that event, a "risky connection"13, so strongly highlighted by Latour, took place in the form of disturbance of the mass death algorithm. The dog shown in Morgenstern's movie rebels against its assigned role - when unleashed, it does not attack its victims, and instead, with a joyful bark, joins a young boy playing with a paper

12 David L. Clark, "On Being 'the Last Kantian in Nazi Germany': Dwelling with Animals After Levinas", in Animal Acts: Configuring the Human in Western History, eds. Jennifer Ham and Matthew Senior (New York: Routledge, 1997), 165-198. 
fan. The animal pays a high price for its spontaneous gesture - guards start to abuse and torment it. When the doors of the "ambulance" are shut, the last sounds the victims hear is an outcry of a beaten dog, and of birds singing in the distance.

The animal, by immersing itself in the joy of play, has dismantled the "operational script" of the crime and abandoned the role of being a tool of the Holocaust. Against the claims of Luc Ferry, who proves that an animal - contrary to a human being - cannot distance itself from a code in which it was anchored ${ }^{\mathbf{1 4}}$, it is the dog of this anti-fairytale, which is assigned a privilege of not so much a moral judgment, but of transgression of conditionings that determine it.

Not only does the rustic element cancel the rigors of the Nazi "tekhne", but it also introduces shifts in the epistemological framing, which explicates the mechanism of the Holocaust and the roles of its participants. It shows that Hilberg's triangle (perpetrator - victim - bystander) ${ }^{\mathbf{1 5}}$, which is fundamental for the historians of the Holocaust, is an imperfect construct, because in order to encompass all dimensions of an event such as the Holocaust, it should become a model - potentially - of more dimensions. It is the dog, with its spontaneous (moral? communal?) reflex, as an element from outside human world, that turns out to be a fourth element of Hilberg's epistemic figure.

An animal (and the world of nature) reveal themselves in the context of liminal situations, and mark the focal points for cultural post-catastrophism, which results in presenting a "concentration camp universe" as an event verifying the understanding of history and historicity. It is not a coincidence that Benjamin's Angel of History (inspired by Paul Klee's painting) appears to be an ontological hybrid, almost an animal, which recognizes ruins of civilization through its motion directed backwards. An eco-critical philosopher would say that this civilization collapsed because it subordinated the development of its "carnophallogocentrism" idea (Derrida), which is displayed via the strive to possess and consume Others. Agamben ${ }^{\mathbf{1 6}}$, when reinterpreting Kojeve, stated that transgressing boundaries between humanity and animality would take place in the moment of the messianic fulfillment of history - the acceptance of an internal animal will become an act of liberation from the trap of dependency, and oppressive power of subject over object.

14 See review of Luc Ferry The New Ecological Order (Chicago: 1995) by C. Wolfe "Ecology, Animal Rights, and the Poverty of Humanism", Diacritics, 30 (Summer 1998).

15 Raul Hilberg, Sprawcy, ofiary, świadkowie: zagłada Żydów: 1939-1945, (The Destruction of European Jews) (Warsaw: Centrum Badań nad Zagładą Żydów, 2007). 
Not many literary works thematize with equal radicalism that same conviction as Goldi does - an auto-biographical novel by Ewa Kuryluk. This confusing, from a research point of view, book tells a family history, which is saturated with distant echoes of historical events: the Second World War, the Holocaust, the Polish intelligentsia's involvement in communism, questions of anti-Semitism and the March 1968 events. However, these dramatic events which are deeply rooted in Polish historical awareness are barely recognizable in the text. One could say they exist as unclear marks, multiple reflections, or ricochets of presented processes, hidden and camouflaged in a meandering and static narration with an unclear system of references.

There is a temptation to refer back to Adrienne Rich, the recently deceased author of OfWoman Born: Motherhood as Experience and Institution ${ }^{17}$. Rich defines the difference between the patriarchal and pre-patriarchal social systems as an opposition between "power over others" and the (feminine) "power of transformation" immersed in the world of nature. Matriarchy operated without hierarchy and domination, and its reason for being was a, transformation of its essence (bordering on magic) which follows the rhythms of nature (according to Rich, birth was marked as a transformational ritual in matriarchy).

Despite visible analogies between the revisionist potential of mythographic feminism and ecology, the revelations of Rich seem too anthropocentric from the perspective of eco-criticism. One could state that another stage of liberation from the yoke of "carnophallogocentric subjects" is established by Kuryluk's "apotheosis of animality" with a visible, utopian vision of "pluriversum" - Latour's society rejecting mechanisms of exclusion ${ }^{\mathbf{1 8}}$ - on the horizon of her book.

Animals in Kuryluk's narration are in captivity, and forced into frameworks of the human world. Domestication, however, does not destroy their sovereignty and does not transform into a brutal domination. On the contrary, in Kuryluk's family from the novel, a reverse process takes place - there is a gradual animalization of people. The process takes the form of nicknaming ("Paws" becomes father's new name - his animal mark) and Peter's madness is interpreted as an answer to "animal Auschwitz", an unending captivity and massacre of non-human beings.

There was a long silence, broken by mom's whisper: "After I came back from the clinic they didn't play 'signals' any more. Next, Goldi passed

17 Adrienne Rich, Of Woman Born: Motherhood as Experience and Institution (W. W. Norton \& Company, 1995) 
away, and Peter started collecting bugs. While in Tworki he could hear voices of animals inside of him, and kept murmuring: "Auschwitz, Dachau, punishment". He refused to eat meat. Mom stared at a bookshelf, where Goldi used to stand. Peter took a rubber piggy bank with a coin slot between its ears with him to Warsaw. "I'm hiding it here, you cry baby" he used to say to Zaza after your death, "so it won't get lost". Einstein Goldi always kept something in his bag for Paws. When he comes back we'll surprise him ${ }^{19}$.

Nature exists in Goldi outside of the discourse of power, and - which is its logical consequence - outside of the power of the discourse. That is why the fabric of this prose is porous, grainy, and the particular sequences and paragraphs appear incohesive. They tend to pile up and split in prismatic time, where the same event - the meeting between a father and a mother escaping the ghetto, the death of the father, the manifestation and the course of a brother's mental illness - is signaled and "tried" in various modalities of the text, as well as various time perspectives. The most painful episodes from mother's pre-war Jewish life that she is almost in denial about become "exiled" from the text in book's last parts through some kind of spasmodic reflex, which cannot be entirely explained by the term 'acting out' in reference to a trauma. It is truly inexpressible "vomit", a deeply abject gesture, hence one that removes ontological divides.

The text becomes an animal, it "animalizes" itself, which can be observed through its dispersed and unstable signification. The process of reading the book is step-like: knots, points, all of which tie together words disintegrating in dialogues, constitute scenes of play with animals, particularly with Goldi the hamster, and Zaza the dog. The scene of Peter's death, taking place next to a bear cage in a city zoo, is a culmination of these transformations. The scenes, seemingly accidental at the beginning, transform into a necessary element of construction of the novel during reading. It is the animals, or the dimension of ontological relations they embody, that counteract the disintegration of the world and text, create a "deep structure" of Kuryluk's acentric narration, constantly in danger of collapsing. When one considers their presence in a broader context, one could say they establish a new "ethical syntagm" which conditions the formulation of moral judgments after a catastrophe. Animals embody Agamben's lost dimension of humanity, and fill the gap in a single-sided technocratic construction of modern man.

19 Ewa Kuryluk, Goldi. Apoteoza zwierzaczkowatości, 2nd ed., (Cracow: Wydawnictwo Literackie, 2011), 140. 


\section{Sebald, or Escape from Marking}

Eco-criticism marks fields of undiscovered meanings of important texts and iconic messages. I think of this potential when I go back to photographs from a series entitled Totenstill by Dirk Reinartz from 1985, which depicted an old location of the Sobibór extermination camp ${ }^{\mathbf{2 0}}$. In that terrifying place, where within couple of months over two hundred and fifty thousand people have been murdered, the only thing that remained after the dismantling of the camp machinery was a meadow slowly being reclaimed by the forest. Reinartz's photographs earned interesting interpretations, which may be read as an attempt at hermeneutical exegesis of those post-memorial images. In this context one should mention above all a well-known essay by Ulrich Baer ${ }^{\mathbf{2 1}}$, which so powerfully describes the emptiness of the traumatic place which according to the will of the author - is granted sense only by a man playing the role of an observer. However, this interpretation - which is obvious from the perspective of eco-criticism - has a categorical, "anthropomorphic" flaw embedded in it. After all, this place is not empty, there is nature, a forest, and uncannily lush vegetation, which establish biocentric inscriptions - voices added to a tragic history of post-concentration camp space. Although contemporary ecology heavily stresses the incomparability of "ethical scenarios" of different forms of being, in this particular case, one can establish - without falling victim to anthropomorphism on the level of description - that nature plays a role of an actant in an ethical space, generating an event in a sphere from which man has retreated. Certainly, a reflection surrounding pictures from Bełżec should consider reevaluating Darwin's opposition between "organism (man) vs. environment" as its starting point, along with its inscribed antagonism as a rule of preserving balance in the world.

Novels and stories by W.G. Sebald repeatedly employ a motif of discrete presence of nature (or rather ungraspable from the perspective of anthropocentric codes), facing an empty space, which was left behind by the dead. It seems that his work appropriates contradicting interpretations of nature that mark the horizon of eco-criticism²2: both autonomous, virgin-like nature unspoiled by man, but always "filtered" through a constructivist consciousness

20 Pictures show the area of a former concentration camp in 1970s and 1980s. In 1993, the Museum of the Former Death Camp in Sobibór has been established to mark the fiftieth anniversary of a prisoners' uprising. schichtsschreibung im Bild", in Niemand zeugt für den Zeugen, 219-235. 
(Die Ringe des Saturn, 1995, Nach der Natur, 1988), as well as the post-industrial, degenerated environment of man (Schwindel. Gefühle, 1990).

Already in the first story from The Immigrants (Die Ausgewanderten, 1992), entitled Dr. Henry Selwyn, the dominating role of nature is revealed. The protagonist and the narrator of the story lives in a garden, spends his time observing blades of grass, their shapes and the forms of life. This introduction could be interpreted both as a symbolic gesture of "stooping" to the level of the world of vegetation, as well as a meta-literary signal revealing the existence of hidden pre-narration, which is always siding with nature in Sebald's prose: it constitutes a bio-, and not anthropogenesis.

Warily we walked round the house. On the north side, where the brickwork was green with damp and variegated ivy partly covered the walls, a mossy path led past the servants' entrance, past a woodshed, on through deep shadows, to emerge, as if upon a stage, onto a terrace with a stone balustrade overlooking a broad, square lawn bordered by flower beds, shrubs and trees. Beyond the lawn, to the west, the grounds opened out into a park landscape studded with lone lime trees, elms and holm oaks, and beyond that lay the gentle undulations of arable land and the white mountains of cloud on the horizon. In silence we gazed at this view, which drew the eye into the distance as it fell and rose in stages, and we looked for a long time, supposing ourselves quite alone, till we noticed a motionless figure lying in the shade cast on the lawn by a lofty cedar in the southwest corner of the garden. It was an old man, his head propped on his arm, and he seemed altogether absorbed in contemplation of the patch of earth immediately before his eyes. ${ }^{23}$

The early volume of stories hints at a possible answer to the question about the reasons for the ungraspable character of nature in the face of the Holocaust. Nature in Sebald's stories always precedes man. The glacier in the Alps, and the English garden from Dr. Henry Selwyn, Cappadocia from Ambros Adelwarth, or the moors of Norfolk from Rings of Saturn constitute an ontological foundation, an arche of man's actions. The systems symbolically created by man are secondary toward nature, that is why it escapes marking, or situating within the system of meaning distinctions.

The hero of Sebald's debut poem, Nach der Natur (1988), faces a similar paradox. Georg Wilhelm Steller went down in history as a deck doctor of an arctic expedition of Vistus Bering, also known as the "great northern

23 Winfried G. Sebald, "Dr Henry Selwyn" in Immigrants, trans. Michael Hulse, (London: Harvill Press, 1996), iBooks edition. 
expedition". He became famous as a researcher of sub-polar fauna (he was the first to describe a sea cow, soon to be eradicated by fur traders), and a collector of scientific artifacts, who brought sixteen cases of valuable anatomical collections from Bering's expedition. Steller's experience becomes a repetition of the archetypical gesture of conquest of nature, and taming of biodiversity through scientific cognitive and classifying procedures in Sebald's interpretation.

Sebald's reading of Steller's biography becomes more understandable when we try to situate it in the context of Latour's account from an expedition to the Amazon - a photo-philosophical, scientific essay entitled Circulating Reference ${ }^{\mathbf{2 4}}$. Bruno Latour analyzed the work of scientists researching, on the basis of soil samples, processes taking place between the savanna and the tropical forest of Boa Vista in Brazil. In that extremely important study, Latour describes a process of "transfer from soil to code" as a series of transformations grasping the essence of a tropical forest into geodesic nets, charts, and measurements of a tableau-comparator. The task, which Latour sets for himself is to formulate an answer to the question about what is the category of reference in a research process. In his final conclusion he states that the mythical "truth of the forest" is not a research conclusion, but what is left after the entire chain of cognitive transformations, sometimes complicated and abstract, and sometimes incredibly simple, like pointing to a boundary between a tropical forest and sandy savanna. Latour does not leave any doubts: the process of situating an object (a forest) in a discourse has an imperialistic dimension, since it marks passage from independence to world domination. Inescapably, it also has a reductionist effect. Latour states: "scientists dominate over the world only to such an extent, as to which the world decides to meet them halfway in the form of two dimensional inscriptions, prone to code combinations" 25 .

The presence of a gesture of desemantization of the scenery, which is fundamental for Sebald's writerly practice, becomes fully understandable in that context. Nature does not play any metaphorical functions, does not constitute semantics, or require from its protagonists hermeneutical activities, even though it exits in a relation to human history. This relationship with historicity should be described as a non-insistent durée, contrapuntal against the rapidly changing world of man. That is why the protagonists of Sebald, those who experienced historical traumas - exiles, children of Holocaust

24 Bruno Latour, "Zirkulierende Referenz. Bodenstichproben aus dem Urwald Amazonas" in Die Hoffnung der Pandora. Untersuchungen zur Wirklichkeit der Wissenschaft, trans G. Rossler, (Frankfurt am Main Suhrkamp Verlag, 2000). 
victims, victims of political and racial oppression - search for nature as a framing of their post-traumatic neurosis. According to a paradox, they are often accompanied by images of nature in its sublime representations, so eagerly employed in totalitarian iconography: mountain peaks, a storm at sea, Alpine meadows, or - in absolute contradiction - a post-industrial wasteland.

Are Sebald's protagonists interested in removing cultural and historical mediations and, subsequently, arriving at "nature in itself", even if it were to be another intellectual construct? It seems to be a very unlikely interpretation, especially when we realize that one of most notorious practices of Sebald was to expose all naturalized mediations. Photographs, so characteristic for his prose, are used precisely with that purpose in mind. They are used in phototextual narrations in a function of a double, which destroys faith in the existence of a source of representations, as well as debunks claims of realism to a mimetic rule over reality.

I do not believe that these men sit by the sea all day and all night so as not to miss the time when the whiting pass, the flounder rise or the cod come in to the shallower waters, as they claim. They just want to be in a place where they have the world behind them, and before them nothing but emptiness. The fact is that today it is almost impossible to catch anything by fishing at the beach. The boats in which the fishermen once put out from the shore have vanished, now that fishing no longer affords a living, and the fishermen themselves are dying out. No one is interested in their legacy. Here and there one comes across abandoned boats that are falling apart, and the cables with which they were once hauled ashore are rusting in the salt air. Out on the high seas the fishing continues, at least for the present, though even there the catches are growing smaller, quite apart from the fact that the fish that are landed are often useless for anything but fish-meal. Every year the rivers bear thousands of tons of mercury, cadmium and lead, and heaps of fertilizer and pesticides, out into the North Sea. A substantial proportion of the heavy metals and other toxic substances sink into the waters of the Dogger Bank, where a third of the fish are now born with strange deformities and excrescences. Time and again, off the coast, rafts of poisonous algae are sighted covering many square miles and reaching thirty feet into the deep, in which the creatures of the sea die in shoals ${ }^{26}$.

26 Winfried G. Sebald, The Rings of Saturn, trans. Michael Hulse (London: Harvill Press, 1998), iBooks edition, 77-78. 
What is symptomatic, however - despite the grand "praise of bio-diversity" - is that a careful reading of The Rings of Saturn suggests a conclusion, in which simultaneously passing landscapes of Suffolk dunes, or of Alpine meadows in Sebald's prose are, in truth, modalities of one and the same landscape. It is a coherent landscape with thick, undifferentiated texture, as if it played a function of essence abstracted from that which is clear, phenomenal. Nature in Sebald's prose is always in a state of maximum focus, and strongly saturated with materiality. At the same time, it is always identical with itself, does not undergo alienation, does not "unglue" from its ontological background and never gets lost in complex representations marked by contradictions. Only man breaks up continuity, and introduces dissonances with a stigma of conflict of fracture.

In general, Sebald, even though gently, refers to the tradition of the English pastoral novel - with its vision of antagonism-free relationships in the universe - and builds a dystopian vision of a "world after nature", where a man is immersed in nihilism and cosmic loneliness. What is characteristic, nature in Sebald's works, in a very gentle, subdued way, reveals its state of exhaustion, which indirectly corresponds with his literary topos - emptiness left after Jewish inhabitants in German and Czech towns. It is a nature reaching its limits, struck by the sheer scale of the crime, results of which have transgressed boundaries of man's world. 